\title{
Treatment with nitric oxide and seed coat removal improve germination and growth of rubber (Hevea brasiliensis)
}

\author{
N M C Nayanakantha*, K D Madhushani**, L A R Amarathunga*, \\ G A S Wijesekera*, P D Pathirana*, W Karunatilaka*, D L N de Zoysa*, \\ M N de Alwis*, R Handapangoda* and P Seneviratne* \\ * Plant Science Department, Rubber Research Institute of Sri Lanka, Dartonfield, \\ Agalawatta, Sri Lanka \\ ** Department of Crop Science, University of Ruhuna, Mapalana, Kamburupitiya, Sri Lanka
}

\begin{abstract}
Studies were carried out on the effect of seed coat removal and nitric oxide (NO) donor sodium nitroprusside (SNP) treatment on germination and growth of seedling and budded plants of rubber (Hevea brasiliensis). Interaction effects were observed between seed coat treatment and SNP treatments for germination time and percentage germination. Decoated seeds germinated earlier and improved synchronicity than intact seeds (with seed coat) and achieved $50 \%$ germination within nine days. SNP treatment at all four concentrations (20, 50, 100 and $200 \mu M)$ hastened the germination and increased the percentage germination especially when decoated seeds were used. Shoot and root attributes of seedlings (stock plants) derived from the seeds treated with SNP, especially at 50-100 $\mu \mathrm{M}$, were significantly improved as compared to those from control and mock treated seeds. Growth of the budded plants were better when stock plants derived from SNP treated seeds were used. Therefore, NO treatment coupled with decoating could effectively be utilized to improve the germination and growth of seedling and budded plants of rubber. To our knowledge, this is the first report on redox priming of rubber seeds with SNP.
\end{abstract}

Key words: germination, growth, nitric oxide, rubber, sodium nitroprusside

\section{INTRODUCTION}

The quality of planting material and an optimum stand of vigorous plants are of utmost importance to achieve the potential yield of rubber (Hevea brasiliensis) clones (Nugawela, 2010). In order to produce high quality rubber plants, both the rootstock and the budwood should be of high quality (Seneviratne and Wijesekara, 2011). Rubber seeds are used to generate root stock plants to be budgrafted with desirable clones. Rubber seeds are recalcitrant and have high moisture content at maturity (Chin, 1995). Recalcitrant seeds germinate rapidly 
Nitric oxide improves germination of rubber seeds

when sown fresh, but are sensitive to desiccation and freezing and hence difficult to store (McDonald, 2004). Fresh rubber seeds generally take 7-10 days to start germination in a sand bed. Vigorous seeds should be selected to raise stock plants by collecting early germinates. About $50 \%$ of the early germinates should be harvested every other day, only for three rounds, although entire population germinates (Anon, 2013). Vigorous seedlings become buddable in 3-4 months under proper agro- management practices (Anon, 2013).

However, for government rubber nurseries, seeds are purchased from different suppliers who collect and store seeds for a few days to weeks to supply them in bulk quantities. These seeds generally take 2-3 weeks to start germination and 3-4 weeks to achieve $50 \%$ germination. Although it is recommended to transplant the seedlings into polybags at the radicle emergence stage under normal condition (Anon, 2013), transplanting is generally delayed by the nursery men until the leaf emergence stage due to various reasons. Due to asynchronous germination of rubber seeds, a number of vigorous seedlings that immerge earlier grow faster when the rest germinate. During transplanting, somewhat mature seedlings are compelled to be discarded and hence the vigorous seedlings are lost. Further, it frequently forces the nurseries to extend the budgrafting period for up to six months as they wait for late-germinating seedlings also to achieve buddable size. Therefore, it is essential to find ways to speed up and improve synchronous germination and increase percentage germination of rubber seeds.

The coat is thick and hard in rubber seeds and therefore can act as a physical barrier for germination. Seed coat removal is a mechanical scarification method to improve the germination and ensure uniform seedling emergence (Kimura and Islam, 2012). Previous studies indicated that removal of seed coat of certain woody perennial species producing orthodox seeds viz., pine (Saeed and Thanos, 2006), Rauvolfia serpentine (Paul et al., 2008), Quercus serrata Thunb. and Quercus semecarpifolia Sm. (Pandey and Tamta, 2013), Grevillia spp (Morris et al., 2000) and citrus (Girardi et al., 2007) would enhance germination and uniformity, increase percentage germination and enhance seedling performance. However, only a few reports are available on studies of seed coat removal in recalcitrant woody perennials such as Mango (Muralidhara et al., 2016) and Avocado (Bergh, 1988). Therefore, one can expect that decoating (complete removal of seed coat) would improve germination of rubber seeds.

Soaking of seeds in water (hydropriming), inorganic salt solution (halopriming) or hormone solution (homopriming) has been reported as common priming techniques for enhanced germination dynamics in many crop plants such as wheat, rice (Dorna et al., 2014) and lentil (Ghassemi-Golezani, 2008). It is well known that plant hormones can impact seed dormancy and improve 
N M C Nayanakantha et al.

germination in crop species. For example, abscisic acid (ABA) generally inhibits germination (Gubler et al., 2005), whereas gibberellic acid (GA) promotes germination (da Silva et al., 2004).

More recently, it has become apparent that molecules, such as nitric oxide (NO) can significantly impact on plant growth and development from seed germination up to senescence (Mur et al., 2012). Redox priming with NO donor sodium nitroprusside (SNP) has been shown to enhance germination and/or break dormancy in orthodox seeds such as Barley (Bethke et al., 2004), lettuce (Beligni and Lamattina, 2000), rice (Habib et al., 2010), wheat (Hua et al., 2003), switchgrass (Sarath et al., 2006) including Arabidopsis thaliana (Bethke et al., 2006a). Nevertheless reports on NO implication in recalcitrant seeds, including rubber, is scarce (Bai et al., 2011).

NO is required for root organogenesis (Pagnussat et al., 2002), lateral root development (Correa-Aragunde et al., 2004) and improve growth and development of many crop plants especially under abiotic stress conditions (Mur et al., 2012, Kong et al., 2014). Nayanakantha et al. (2014) demonstrated that treatment with NO donor SNP improved growth and root characteristics of rubber seedlings in a dose dependent manner. Therefore, this study was undertaken to ascertain the effectiveness of seed coat removal and NO treatments on germination dynamics and growth performance of seedling and budded plants of rubber. We report here that, exogenous NO donor SNP and decoating treatments hastened germination, improved synchronicity and percentage germination and growth of rubber plants

\section{Materials and methods}

The study was conducted in a nursery at the Dartnofield Estate of the Rubber Research Institute of Sri Lanka (RRISL). Fresh rubber seeds from the clone BPM 24 were collected at the early seed fall from Millewa estate, Padukka and brought to RRISL. Half of the seed lot was manually decoated and other half left intact. Both intact and decoated seeds were treated as follows: no soaking (control), soaked in water for 6 hours or in $20,50,100$ and $200 \mu \mathrm{M}$ SNP for 6 hours.

Seeds were sown in a germination bed filled with sand in to a randomized complete block design (RCBD) with four blocks. There were 4 replications of 50 seed each in each treatment in each block, with a total of 2,400 seeds. Germination beds were watered once daily. Cumulative seed germination percentage was recorded at $7,9,11,13$, $15,17,19$ and 21 days after sowing. Seeds were considered as germinated when the radicle had protruded about 2 $\mathrm{mm}$, regardless of seed coat.

Each germinated seedlings were transplanted in black polythene bags, gauge 300 and having lay-flat dimensions of $15 \mathrm{~cm}$ diameter and 37 $\mathrm{cm}$ height, filled with soil. Soils from the Agalawatta series were collected from the surface layer $(0-15 \mathrm{~cm}$ depth), sieved through a $1 \mathrm{~cm}$ mesh to remove large lateritic gravel before filling the bags. Polybags were arranged in a 
Nitric oxide improves germination of rubber seeds

nursery according to a RCBD with eight blocks, each treatment containing five plants so that the total number of plants for each treatment was forty. Two weeks after transplanting, application of chemical fertilizers, i.e. young budding fertilizer mixture in liquid form, into seedlings was started and carried out at two-week intervals. All other management practices were same as recommended by the Rubber Research Institute of Sri Lanka (Anon, 2013).

\section{Measurement of growth parameters of seedlings}

Growth attributes of rubber seedlings were assessed after three months from transplanting. Ten plants from each treatment were removed and root system was washed gently under running water over a $0.5 \mathrm{~mm}$ sieve and the adhering soil and dust particles were carefully removed. Morphological attributes viz., diameter of stem, plant height and number of leaves were recorded. Leaf area was determined by leaf area meter (Model L1-3100, LICOR, USA). Chlorophyll content was measured using SPAD 502 Plus chlorophyll meter. Dry weights (DW) of shoots and roots were obtained by ovendrying the samples at $70{ }^{\circ} \mathrm{C}$ for 48 hours.

\section{Measurement of growth parameters of budded plants}

Seedlings were budgrafted with PB 260 clone after three months from transplanting. Percentage budgrafting success was recorded after one month. When the first leaf whorl was matured, growth attributes viz., number of leaves, leaf area, chlorophyll content of leaf and dry weight of scion shoots were recorded.

\section{Data analysis}

Germination data was subjected to arcsin transformation before being submitted to analysis of variance. However, actual percentages are presented. Growth data before and after budgrafting were analyzed according to two-factor factorial experiment (with/ without seed coat and five levels of SNP). Significance of the observed treatment differences was tested by analysis of variance using proc GLM procedure of the SAS software package (version 9.1) and significant means were separated using Duncan's Multiple Range Test (DMRT) at the 5\% probability level.

\section{Results \\ Seed germination}

Results of the present study revealed that there were interaction effects between seed coat treatment and soaking treatments for germination time and percentage germination. A significantly higher germination percentage was recorded from decoated seeds than from intact seeds for up to thirteen days from sowing when the factor 1 (soaking treatment) was fixed (Fig. 1). The first visible germination occurred as early as four days after sowing when several seeds with radical perturbation were observed from decoated seeds treated with SNP. However, by seventh day after sowing, a significantly higher germination 
N M C Nayanakantha et al.

percentage was recorded from seeds treated with SNP, especially at $50 \mu \mathrm{M}$ -
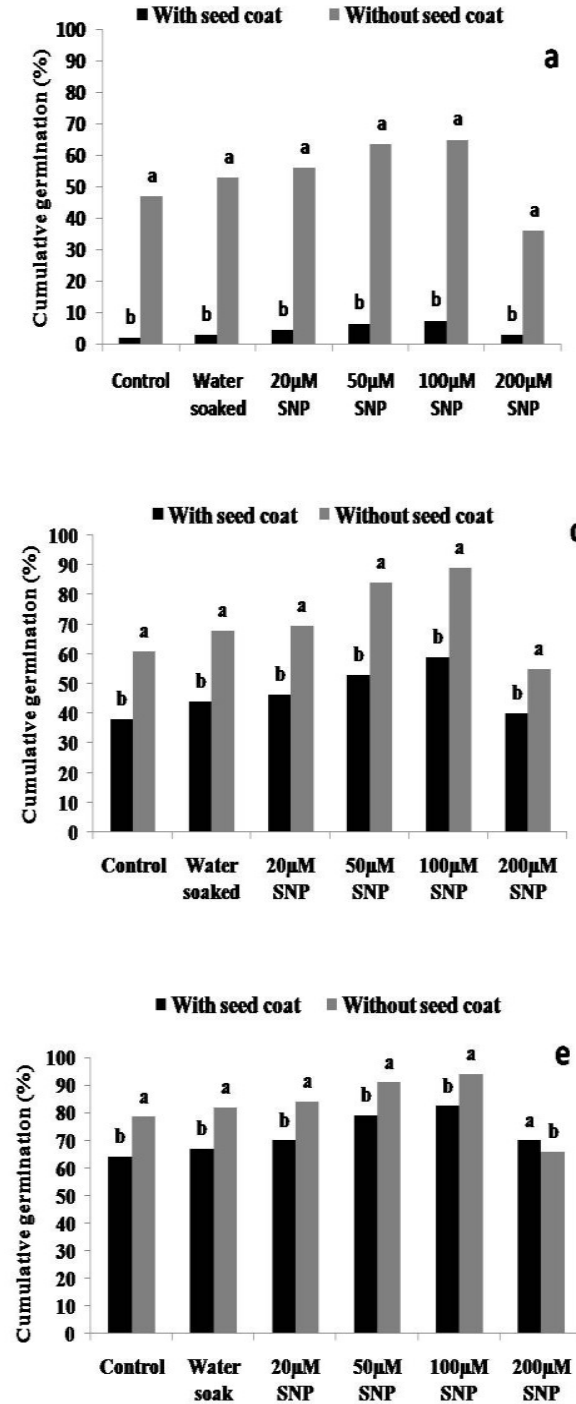

$100 \mu \mathrm{M}$, when the factor 2 (seed coat treatment) was fixed (Fig. 2).
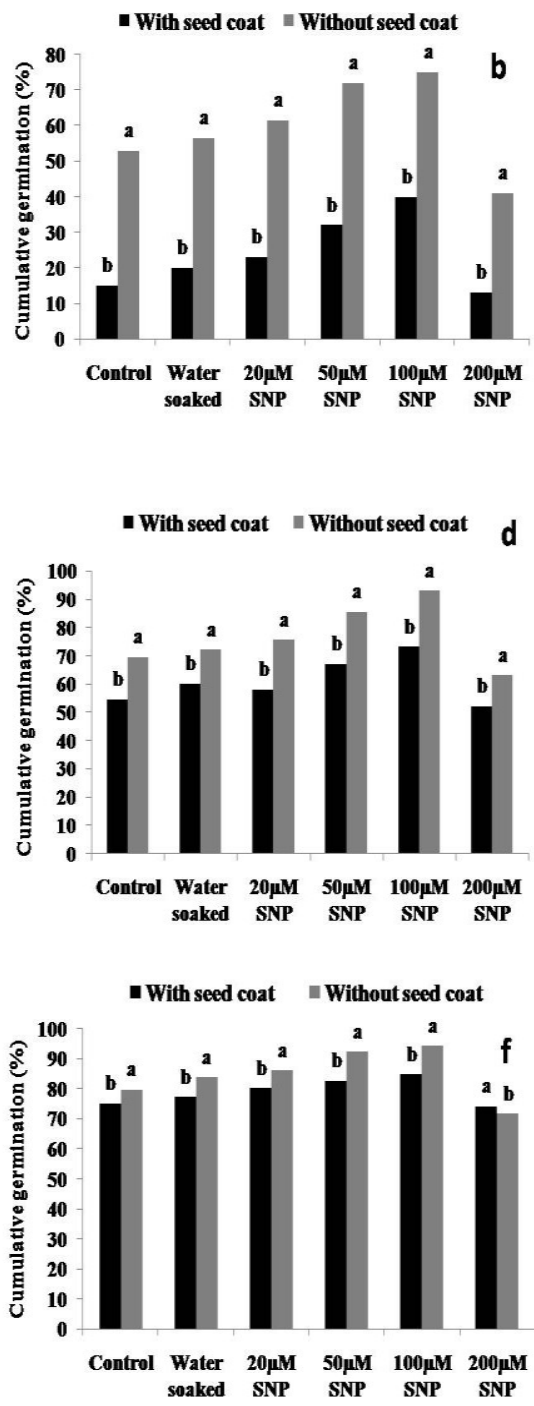

Fig. 1. Effect of seed coat on germination percentage of rubber seeds when the factor 1 (soaking treatments with SNP) was fixed. a) after 7 days, b) after 9 days, c) after 11 days, d) after 13 days, e) after 15 days and f) after 21 days from sowing. Means with same letter between two adjacent bars are not significantly different at $p \leq 0.05$ 
Decoated seeds devoid of soaking treatments took only 9 days to complete
$50 \%$ germination whilst intact control seeds required 13 days (Fig. 1).
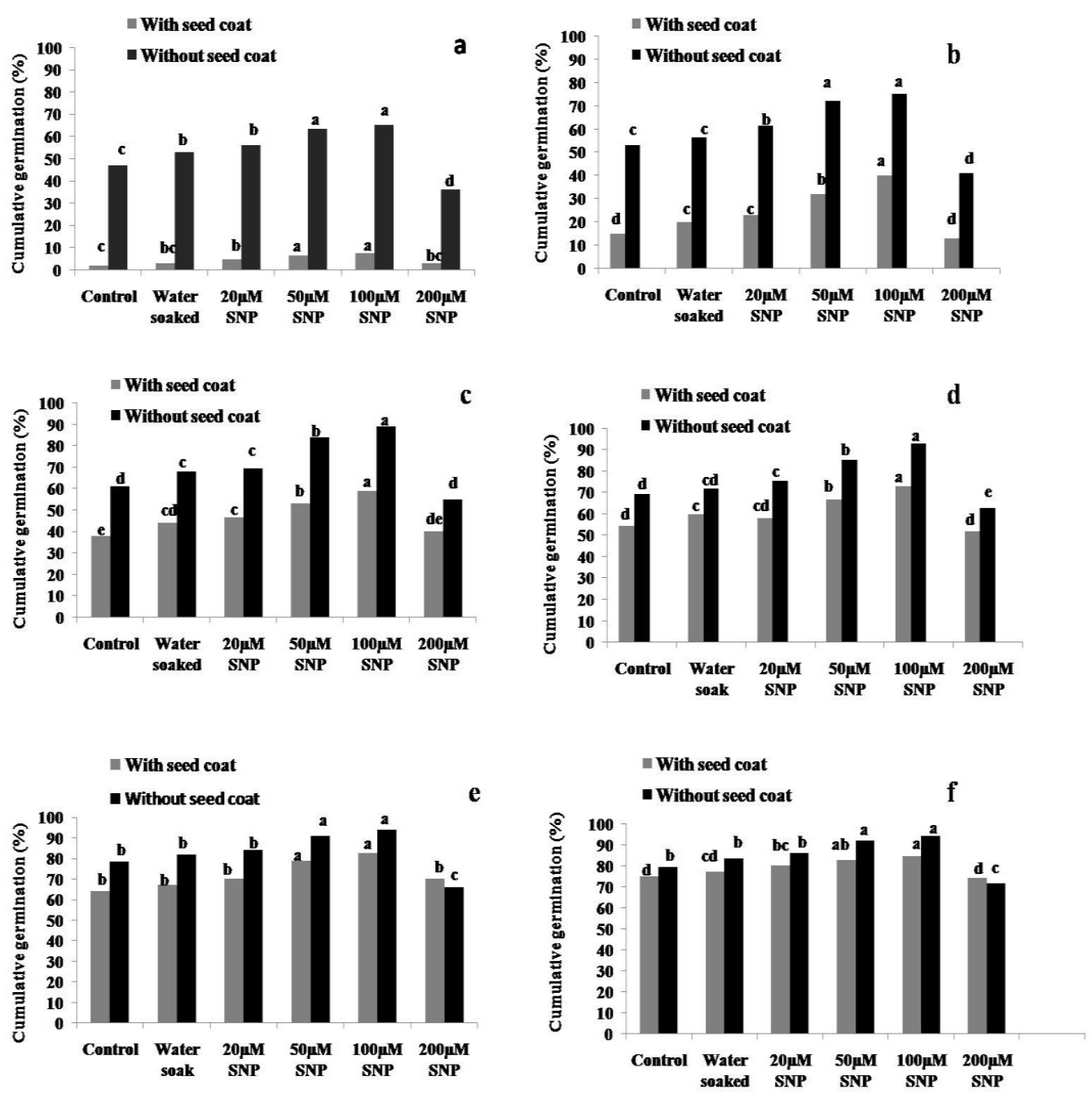

Fig. 2. Effect of NO donor SNP on germination percentage of rubber seeds when the factor 2 (seed coat treatment) was fixed. a) after 7 days, b) after 9 days, c) after 11 days, d) after 13 days, e) after 15 days and f) after 21 days from sowing. Means with same letter among bars for different SNP concentrations are not significantly different at $p \leq 0.05$. 
N M C Nayanakantha et al.

SNP treatment greatly hastened the germination and increased percentage germination in both decoated and intact seeds. By the $13^{\text {th }}$ day after sowing, $93 \%$ of decoated seeds and $73 \%$ of intact seeds had germinated upon SNP treatment at $100 \mu \mathrm{M}$ as compared to those devoid of soaking treatments, $69.5 \%$ for decoated seeds and $54.5 \%$ for intact seeds (Fig. 2). Nevertheless, by the $21^{\text {st }}$ day after sowing, $75 \%$ of the intact seeds (control) had germinated while $79.5 \%$ of the decoated seeds devoid of soaking treatments had germinated (Fig. 1).

\section{Seedling attributes}

Interactive effects were observed only for dry weight of shoots and chlorophyll content between seed coat treatment and SNP treatments after three months from transplanting into polybags (Fig. 3, 4, 5 $\&$ 6). Seedlings derived from SNP treated seeds, in dose dependent manner, showed improved shoot and root characteristics as compared to those derived from control and mock treated (water soaked) seeds after three months from transplanting into polybags.
Seedlings derived from decoated seeds devoid of soaking treatments and SNP treatment at $20 \mu \mathrm{M}$ showed a higher chlorophyll content than that from their respective intact seeds (Fig. 6). Nevertheless, seedlings derived from intact seeds with mock treatment and treated with SNP at 50-200 $\mu \mathrm{M}$ showed a higher chlorophyll content than that from their respective decoated seeds (Fig. 5). Nevertheless, $100 \mu \mathrm{M}$ SNP was most effective for the increment in chlorophyll content in seedlings derived from both decoated and intact seeds. Interestingly SNP treatment at all four concentrations $(20 \mu \mathrm{M}, 50 \mu \mathrm{M}, 100 \mu \mathrm{M}$ and $200 \mu \mathrm{M}$ ) showed a significantly higher shoot dry weight as compared to control and mock treatment when intact seeds were used (Fig. 3). However, when decoated seeds were used, 200 $\mu \mathrm{M}$ SNP was not effective (Fig. 6). Nevertheless, soaking of seeds in a 100 $\mu \mathrm{M}$ SNP solution was most effective for the increment in shoot dry weight in seedlings derived from both decoated and intact seeds. 


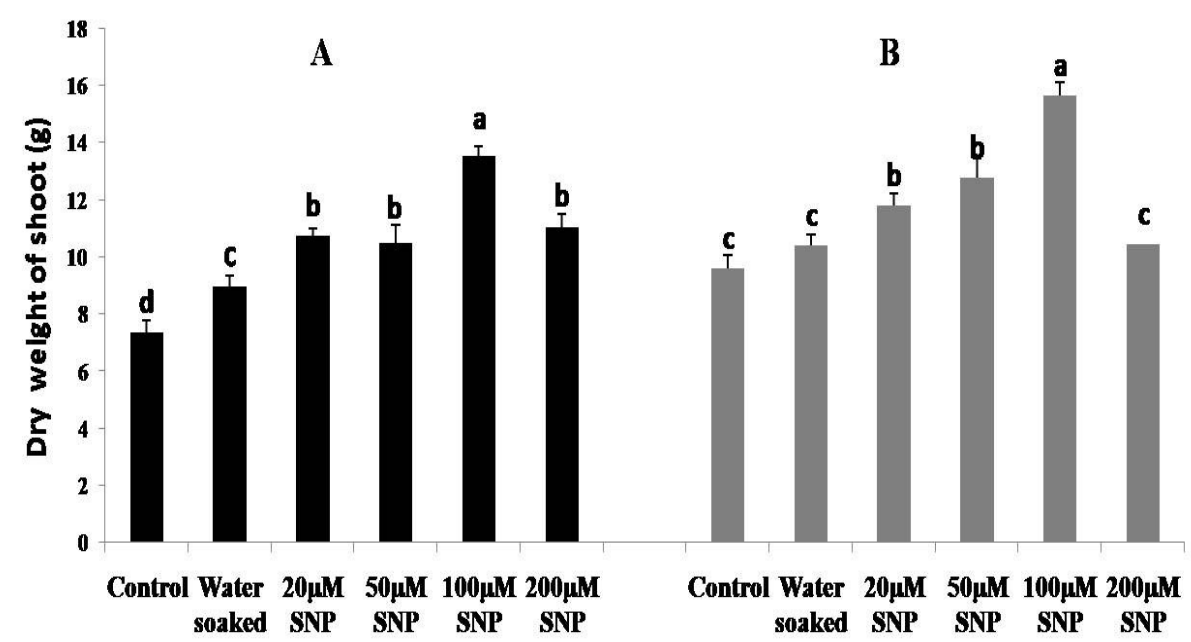

Fig. 3. Effect of NO donor SNP on shoot dry weight of rubber seedlings after three months from transplanting, when the factor 2 (seed coat treatment) was fixed. A) intact seed, B) decoated seed. Letters indicate significant difference at $p \leq 0.05$ according to DMRT.

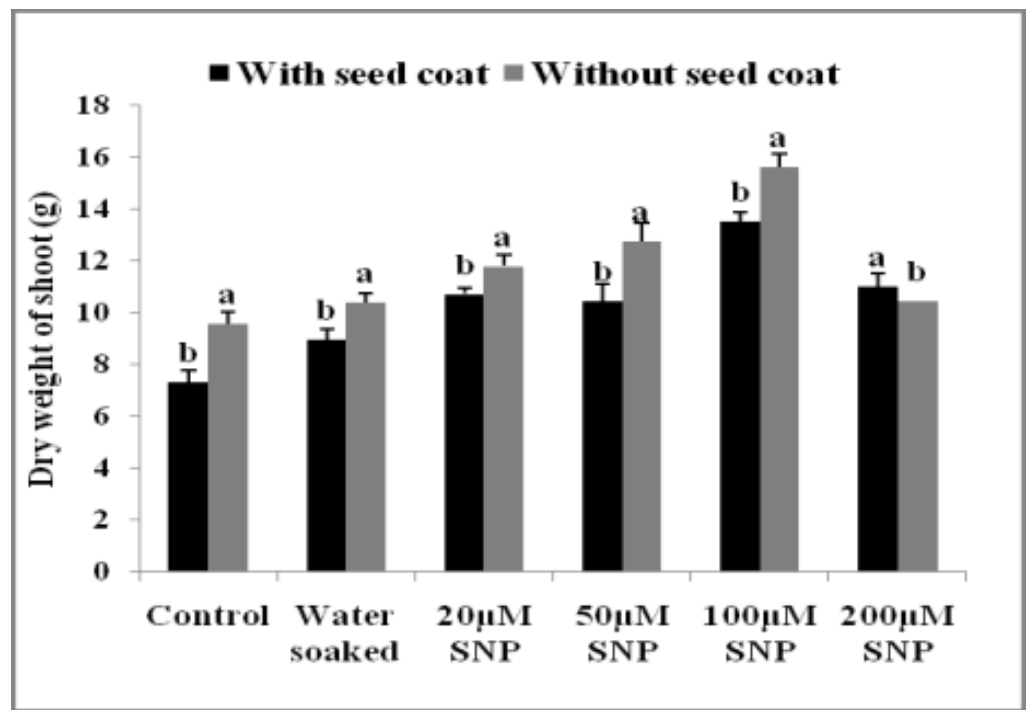

Fig. 4. Effect of seed coat treatment on shoot dry weight of rubber seedlings after three months from transplanting, when the factor 1 (soaking treatment with SNP) was fixed. A) intact seed, B) decoated seed. Letters indicate significant difference at $p \leq 0.05$ according to DMRT 


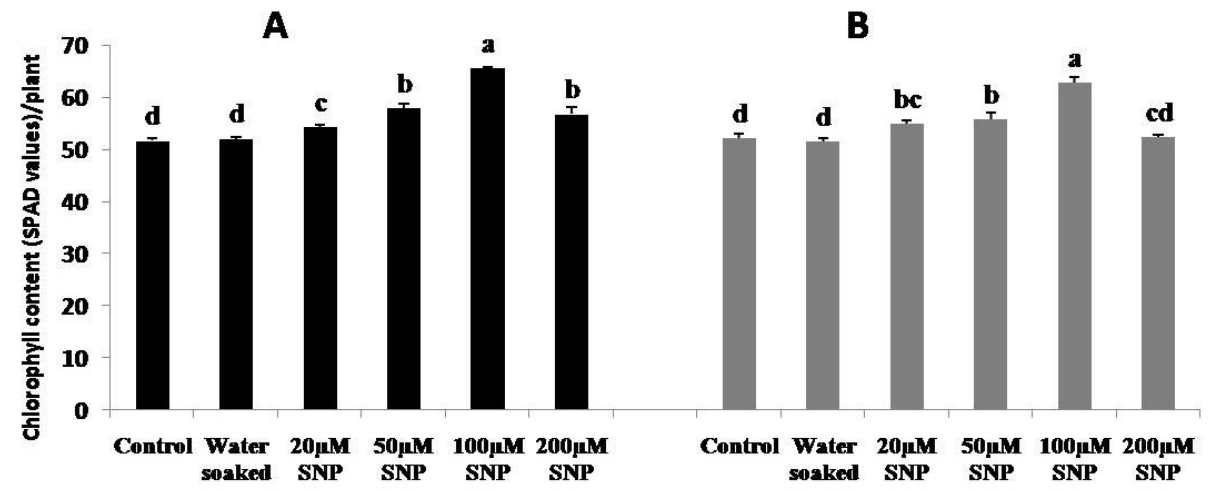

Fig. 5. Effect of NO donor SNP on chlorophyll content of rubber seedlings after three months from transplanting, when the factor 2 (seed coat treatment) was fixed. A) intact seed, B) decoated seed. Letters indicate significant difference at $p \leq 0.05$ according to DMRT.

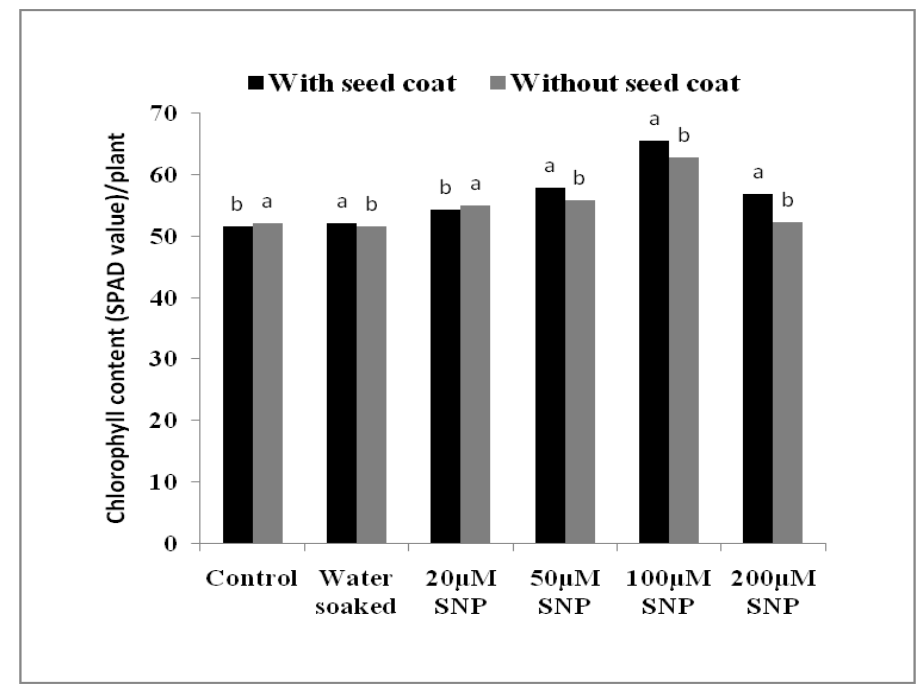

Fig. 6. Effect of seed coat removal on chlorophyll content of rubber seedlings after three months from transplanting, when the factor 1 (soaking treatment with SNP) was fixed. A) intact seed, B) decoated seed. Letters indicate significant difference at $p \leq 0.05$ according to DMRT 
Nitric oxide improves germination of rubber seeds

Shoot characteristics viz., stem height, stem diameter and leaf area significantly increased with SNP treatment, especially at $100 \mu \mathrm{M}$, as compared to control and mock treatment (Table 1). Nevertheless, there was no significant difference in stem height, stem diameter, number of leaves and leaf area between seedlings derived from decoated seeds and intact seeds (Table 2). Tallest plants were produced when seedlings were derived from seeds treated with SNP at $200 \mu \mathrm{M}$ (Table 1).

Table 1. Effect of seed treatment with NO donor SNP on shoot characteristics of rubber seedlings after three months from transplanting into polybags

\begin{tabular}{lllll}
\hline Treatment & $\begin{array}{l}\text { Stem height } \\
\text { (cm/plant) }\end{array}$ & $\begin{array}{l}\text { Stem diameter } \\
\text { (mm/plant) }\end{array}$ & $\begin{array}{l}\text { No. of leaves } \\
\text { (per plant) }\end{array}$ & $\begin{array}{l}\text { Leaf area } \\
\text { (cm } / \text { plant) }^{\mathrm{d}}\end{array}$ \\
\hline Control & $65.36 \pm 1.18^{\mathrm{d}}$ & $8.07 \pm 0.07^{\mathrm{cd}}$ & $9.8 \pm 0.44^{\mathrm{a}}$ & $888.55 \pm 20.75^{\mathrm{c}}$ \\
water soaked & $66.86 \pm 1.13^{\mathrm{cd}}$ & $7.88 \pm 0.14^{\mathrm{d}}$ & $9.8 \pm 0.36^{\mathrm{a}}$ & $921.71 \pm 16.67^{\mathrm{bc}}$ \\
$20 \mu \mathrm{M} S \mathrm{SP}$ & $68.86 \pm 1.11^{\mathrm{c}}$ & $8.61 \pm 0.16^{\mathrm{b}}$ & $9.8 \pm 0.36^{\mathrm{a}}$ & $977.66 \pm 19.21^{\mathrm{b}}$ \\
$50 \mu \mathrm{M} \mathrm{SNP}$ & $69.72 \pm 0.83^{\mathrm{c}}$ & $8.75 \pm 0.12^{\mathrm{b}}$ & $10.1 \pm 0.46^{\mathrm{a}}$ & $963.89 \pm 19.63^{\mathrm{bc}}$ \\
$100 \mu \mathrm{M} \mathrm{SNP}$ & $73.01 \pm 1.54^{\mathrm{b}}$ & $10.63 \pm 0.31^{\mathrm{a}}$ & $10.0 \pm 0.21^{\mathrm{a}}$ & $1260.68 \pm 14.88^{\mathrm{a}}$ \\
$200 \mu \mathrm{M} S \mathrm{SP}$ & $84.31 \pm 1.82^{\mathrm{a}}$ & $8.44 \pm 0.19^{\mathrm{bc}}$ & $9.6 \pm 0.43^{\mathrm{a}}$ & $980.09 \pm 33.37^{\mathrm{b}}$ \\
\hline
\end{tabular}

Values followed by the same letter in a column are not significantly different at $\mathrm{p} \leq 0.05$.

Table 2. Effect of seed coat removal on shoot characteristics of rubber seedlings after three months from transplanting into polybags

\begin{tabular}{lllll}
\hline Treatment & $\begin{array}{l}\text { Stem height } \\
\text { (cm/plant) }\end{array}$ & $\begin{array}{l}\text { Stem } \\
\text { diameter } \\
(\mathbf{m m} / \mathbf{p l a n t})\end{array}$ & $\begin{array}{l}\text { No. of } \\
\text { leaves } \\
\text { (per plant) }\end{array}$ & $\begin{array}{l}\text { Leaf area } \\
\mathbf{( c m}^{2} / \text { plant) }\end{array}$ \\
\hline Intact seeds & $68.99 \pm 1.24^{\mathrm{a}}$ & $8.50 \pm 0.15^{\mathrm{a}}$ & $10.1 \pm 0.16^{\mathrm{a}}$ & $1018.85 \pm 24.22^{\mathrm{a}}$ \\
Decoated seeds & $73.73 \pm 1.35^{\mathrm{a}}$ & $8.96 \pm 0.21^{\mathrm{a}}$ & $9.6 \pm 0.25^{\mathrm{a}}$ & $978.68 \pm 30.91^{\mathrm{a}}$ \\
\hline
\end{tabular}

Values followed by the same letter in a column are not significantly different at $p \leq 0.05$. 
N M C Nayanakantha et al.

Table 3. Effect of seed treatment with NO donor SNP on root characteristics of rubber seedlings after three months from transplanting into polybags

\begin{tabular}{|c|c|c|c|}
\hline Treatment & $\begin{array}{l}\text { DW of ESR+ SR } \\
\text { (g/plant) }\end{array}$ & $\begin{array}{l}\text { DW of taproot } \\
\text { (g/plant) }\end{array}$ & $\begin{array}{l}\text { DW of total roots } \\
\text { (g/plant) }\end{array}$ \\
\hline Control & $1.18 \pm 0.03^{\mathrm{c}}$ & $2.50 \pm 0.07^{\mathrm{d}}$ & $3.69 \pm 0.08^{\mathrm{d}}$ \\
\hline Water soaked & $1.26 \pm 0.05^{\mathrm{c}}$ & $2.64 \pm 0.07^{\mathrm{d}}$ & $3.90 \pm 0.08^{\mathrm{d}}$ \\
\hline Soaked in $20 \mu \mathrm{M}$ SNP & $1.48 \pm .05^{\mathrm{b}}$ & $2.86 \pm 0.07^{\mathrm{c}}$ & $4.35 \pm .08^{\mathrm{c}}$ \\
\hline Soaked in $50 \mu \mathrm{M}$ SNP & $1.54 \pm 0.03^{\mathrm{b}}$ & $3.10 \pm 0.07^{\mathrm{b}}$ & $4.65 \pm 0.08^{\mathrm{b}}$ \\
\hline Soaked in $100 \mu \mathrm{M}$ SNP & $2.02 \pm 0.08^{\mathrm{b}}$ & $4.29 \pm 0.08^{\mathrm{a}}$ & $6.31 \pm 0.12^{\mathrm{a}}$ \\
\hline Soaked in $200 \mu \mathrm{M}$ SNP & $1.44 \pm 0.08^{\mathrm{b}}$ & $3.15 \pm 0.09^{\mathrm{b}}$ & $4.60 \pm 0.10^{\mathrm{bc}}$ \\
\hline
\end{tabular}

Values followed by the same letter in a column are not significantly different at $p \leq 0.05$ according to DMRT.

Table 4. Effect of seed coat treatment on root characteristics of rubber seedlings after three months from transplanting into polybags

\begin{tabular}{llll}
\hline Treatment & $\begin{array}{l}\text { DW of ESR+ SR } \\
\text { (g/plant) }\end{array}$ & $\begin{array}{l}\text { DW of taproot } \\
\text { (g/plant) }\end{array}$ & $\begin{array}{l}\text { DW of total roots } \\
\text { (g/plant) }\end{array}$ \\
\hline Intact seeds & $1.45 \pm 0.05^{\mathrm{a}}$ & $3.03 \pm 0.11^{\mathrm{a}}$ & $4.49 \pm 0.16^{\mathrm{a}}$ \\
Decoated seeds & $1.52 \pm 0.05^{\mathrm{a}}$ & $3.15 \pm 0.11^{\mathrm{a}}$ & $4.68 \pm 0.16^{\mathrm{a}}$ \\
\hline
\end{tabular}

Values followed by the same letter in a column are not significantly different at $p \leq 0.05$ according to DMRT.

\section{Budded plant attributes}

There was no effect of SNP or seed coat treatment on budgrafting success. The budgrafting success was $80-85 \%$ in all cases, including the control. Interactive effects were not observed for any of the parameters viz., diameter of the scion shoot, length of the scion shoot, leaf area and chlorophyll content of the leaves between seed coat treatment and SNP treatment (Table 5 \& 6). Nevertheless, growth characteristics of the scion shoots of stock plants derived from seeds with SNP treatment, especially at $20 \mu \mathrm{M}$, were relatively better though statistically not significant. 
Nitric oxide improves germination of rubber seeds

Table 5. Effect of seed treatment with NO donor SNP on scion shoot characteristics of budded rubber plants

\begin{tabular}{|c|c|c|c|c|}
\hline Treatment & $\begin{array}{l}\text { Shoot } \\
\text { diameter } \\
\text { (mm/plant) }\end{array}$ & $\begin{array}{l}\text { Shoot length } \\
\text { (cm/plant) }\end{array}$ & $\begin{array}{l}\text { Leaf area }\left(\mathrm{cm}^{2}\right. \\
\text { /plant })\end{array}$ & $\begin{array}{l}\text { Chlorophyll } \\
\text { content } \\
\text { (SPAD value) }\end{array}$ \\
\hline Control & $5.13 \pm 0.18^{\mathrm{a}}$ & $21.08 \pm 0.73^{\mathrm{a}}$ & $204.48 \pm 19.59^{\mathrm{a}}$ & $40.73 \pm 2.03^{\mathrm{b}}$ \\
\hline Water soaked & $5.69 \pm 0.28^{\mathrm{a}}$ & $26.75 \pm 1.84^{\mathrm{a}}$ & $157.37 \pm 23.72^{\mathrm{a}}$ & $44.55 \pm 1.68^{\mathrm{ab}}$ \\
\hline Soaked in $20 \mu \mathrm{M} \mathrm{SNP}$ & $5.84 \pm 0.31^{\mathrm{a}}$ & $27.36 \pm 2.74^{\mathrm{a}}$ & $229.68 \pm 48.67^{\mathrm{a}}$ & $45.23 \pm 1.61^{\mathrm{ab}}$ \\
\hline Soaked in $50 \mu \mathrm{M}$ SNP & $5.74 \pm 0.25^{\mathrm{a}}$ & $24.73 \pm 2.53^{\mathrm{a}}$ & $164.11 \pm 28.65^{\mathrm{a}}$ & $40.81 \pm 1.59^{\mathrm{b}}$ \\
\hline Soaked in $100 u$ M SNP & $5.44 \pm 0.25^{\mathrm{a}}$ & $21.47 \pm 1.61^{\mathrm{a}}$ & $209.33 \pm 42.15^{\mathrm{a}}$ & $42.61 \pm 1.65^{\mathrm{ab}}$ \\
\hline Soaked in $200 \mu \mathrm{M}$ SNP & $5.62 \pm 0.35^{\mathrm{a}}$ & $22.23 \pm 1.68^{\mathrm{a}}$ & $183.13 \pm 32.93^{\mathrm{a}}$ & $46.27 \pm 1.05^{\mathrm{a}}$ \\
\hline
\end{tabular}

Values followed by the same letter in a column are not significantly different at $p \leq 0.05$ according to DMRT.

Table 6. Effect of seed coat treatment on scion shoot characteristics of budded rubber plants

\begin{tabular}{lllll}
\hline Treatment & $\begin{array}{l}\text { Shoot } \\
\text { diameter } \\
(\mathbf{m m})\end{array}$ & $\begin{array}{l}\text { Shoot length } \\
(\mathbf{c m})\end{array}$ & $\begin{array}{l}\text { Leaf area } \\
\left.\mathbf{( c m}^{2}\right)\end{array}$ & $\begin{array}{l}\text { Chlorophyll content } \\
\text { (SPAD value) }\end{array}$ \\
\hline Intact seeds & $5.54 \pm 0.16^{\mathrm{a}}$ & $24.77 \pm 1.31^{\mathrm{a}}$ & $172.43 \pm 17.80^{\mathrm{a}}$ & $42.74 \pm 0.91^{\mathrm{a}}$ \\
Decoated seeds & $5.62 \pm 0.16^{\mathrm{a}}$ & $23.14 \pm 1.05^{\mathrm{a}}$ & $210.27 \pm 20.46^{\mathrm{a}}$ & $43.99 \pm 1.07^{\mathrm{a}}$ \\
\hline
\end{tabular}

Values followed by the same letter in a column are not significantly different at $p \leq 0.05$ according to DMRT.

\section{DISCUSSION}

Seed germination is temporally defined as the sequence of molecular and physiological events initiated upon imbibition in non-dormant seeds leading to the radicle protrusion through the seed external envelopes (testa and endosperm) that marks the end of germination (Bewley, 1997). Germination ability is regulated by a combination of environmental and endogenous signals with both synergistic and antagonistic effects. The ABA/gibberellins (GAs) balance coordinates the last step of germination with a decrease in ABA leading to a progressive release of its inhibitory effect on endosperm rupture while increase in bioactive GAs levels and enhancing the growth potential of the embryo and inducing hydrolytic enzymes that weaken the barrier tissues (Arc et al., 2013).

Nitric oxide (NO) is an uncharged, gaseous and lipophilic free radical that can readily diffuse across biological membranes. Thus, NO can interact with numerous distinct molecules in plant cells and then acts as a signaling element (Beligni and Lamattina, 2000). 
N M C Nayanakantha et al.

NO is a potent dormancy releasing agent in many species, including Arabidopsis, and has been suggested to behave as an endogenous regulator of this physiological blockage (Arc et al., 2013).

Rubber seeds have not been tested for their response to NO but only for seed coat removal. Data presented in this study, for the first time, demonstrated that exogenous NO donor SNP elicited a significant enhancement in germination as compared to the control in both decoated and intact seeds. NO has been shown to act as a germination promoter and enhance the germination responsive genes to improve the germination in wheat (Hua et al., 2003). Exogenous SNP has been reported to improve germination of rice seeds under salt stressed condition (Habib et al., 2010). Seed pre-incubation (priming) with SNP (redox priming) was also shown to increase salt stress tolerance in wheat (Duan et al., 2007). NO also enhances the seed vigor index under abiotic stress by enhancing germination promoting proteins (Duan et al., 2007). NO has been shown to break seed dormancy in Arabidopsis and barley (Hordeum vulgare L.) (Bethke et al., 2006b) suggesting that $\mathrm{NO}$ is an endogenous regulator of seed germination in these two species.

ABA inhibition of seed germination in many species is well established (Arc et al., 2013). ABA and NO are antagonistic for seed germination (Bethke et al. 2004). NO donor SNP enhanced the positive effect of norfluorazon, an ABA synthesis inhibitor, on dormancy release of Arabidopsis C24 seeds (Bethke et al., 2006a). Moreover, SNP was shown to reduce seed sensitivity to exogenous ABA (Bethke et al., 2006b). Liu et al. (2009) demonstrate that rapidly accumulated NO induces an equally rapid $\mathrm{ABA}$ decrease that is required for the breaking of seed dormancy and germination in Arabidopsis. While ABA determines seed dormancy and inhibits seed from germination, GAs are necessary for seed germination (Liu et al., 2009). Through its antagonistic effects with ABA, GAs are able to release seeds from dormancy. $\mathrm{NO}$ was proposed to act downstream of $\mathrm{H}_{2} \mathrm{O}_{2}$ in enhancing GA biosynthesis (Liu et al., 2009). Considering the previous studies, results of the present study postulate that exogenous NO donor SNP can antagonize $\mathrm{ABA}$ activity but promotes GAs activity in rubber seeds and thereby hastened germination and increase percentage germination in a dose dependent manner.

The present study revealed that decoating (complete removal of seed coat) resulted in significant promotion of rate and final germination of rubber seeds regardless of SNP treatment. Mock treated seeds (decoated seeds soaked in water) also showed an enhanced germination as compared to decoated seeds alone. Since the coat is thick and hard in rubber seeds, decoating apparently relieved any mechanical restraint and/or barriers to gas exchange and water imbibition and 
Nitric oxide improves germination of rubber seeds

thereby hastened a synchronous germination. According to Filho (2005), seed coat regulates the seed imbibition speed, controls gas exchange, causes dormancy, prevent seed deterioration and acting as a barrier to microorganisms entry.

Rawat et al. (1998) demonstrated that the seed coat was very much hard and thick in $Q$. serrata and therefore inhibited the rate of seed germination. Seed coat removal increased the emergence rate of several citrus rootstocks by $30-100 \%$ (Radhamani et al., 1991). The presence of the seed coat in citrus also works as a mechanical barrier to root development during germination because of the reduction in oxygen and carbon dioxide diffusion and seed imbibition (Girardi et al., 2007). Seed coat removal allowed plant emergence about one week earlier than coated seeds, leading to $25 \%$ higher scion and root dry weight for both rootstocks (Rangpur lime and Swingle citrumelo) (Girardi et al., 2007).

There is a correlation between seed coat thickness and germination rate. The thicker the seed coat, the greater the relative increase in plant emergence after seed coat removal. Seed coat external texture also influences plant germination. Therefore, smooth seed coats usually correspond to fastgerminating species (Girardi et al., 2007). Although external seed coat removal is a labor-intensive activity, this procedure may increase seedling emergence and improve plant quality (Sempionato et al., 1997). Since the seed coat of rubber is thick, it is amenable to mechanical removal and hence automation of seed coat removal needs to be investigated as a practical solution for large scale nurseries.

Growth of the rubber seedlings derived from SNP treated seeds, especially at $100 \mu \mathrm{M}$, was improved as compared to those derived from control and mock treated seeds when both decoated and intact seeds were used after three months from transplanting into polybags. Interaction effects were observed between seed soaking treatments with SNP at least for shoot dry weight and chlorophyll contents of leaves. Leaf area increased with SNP pretreatment in a dose dependent manner. Studies conducted during the induction of diverse plant responses have demonstrated that NO may also affect biosynthesis, catabolism/ conjugation, transport, perception, and/or transduction of almost all the phytohormones, i.e. auxins, gibberellins, cytokinins, abscisic acid, ethylene, salicylic acid, jasmonates, and brassinosteroids (Mur et al., 2012). NO is known to enhance de-etiolation and promote greening in young seedlings (Beligni and Lamattina, 2000). Chohan et al. (2012) demonstrated that in chick pea seedlings, leaf areas increased with exogenous SNP as a NO donor. Further, SNP treatment enhanced the accumulation of total dry matter content and partitioning towards different plant parts in chick pea. This could be due to the cumulative effect of SNP through the regulation of cell division, xylem 
N M C Nayanakantha et al.

differentiation and exo-and endo- $\beta$-Dglucanase in the cell wall (Zhang et al., 2003).

Root dry weights also increased significantly at $50-100 \mu \mathrm{M}$ SNP. Synergistic effects of auxin and NO have been observed during the regulation of a series of plant responses, including the interplay between these molecules during adventitious root formation (Pagnussat et al., 2002) and lateral root development (CorreaAragunde et al., 2004). Improved germination dynamics and growth characteristics of rubber seedlings could be attributed to the beneficial effect of SNP as a NO donor in modifying phytohormone signalling pathways and thereby increasing nutrient uptake and effective allocation of photoassimilates. Further research is needed to determine the NO accumulation in germinating rubber seeds. The practicality of decoating treatment under commercial scale nursery conditions is also required to be explored. Abiotic stress tolerance capacity of rubber plants derived from NO treated seeds should also be investigated.

\section{Acknowledgements}

Statistical analysis done by Dr (Mrs) Wasana Wijesuriya is greatly acknowledged.

\section{References}

Anon (2013). Production of Budded Plants. Advisory Circular. Rubber Research Institute of Sri Lanka.

Arc, E, Galland, M, Godin, B, Cueff, G and Rajjou, L (2013). Nitric oxide implication in the control of seed dormancy and germination. Frontiers in Plant Science \& Plant Physiology 4 (346), 1-13. doi: 10.3389/fpls.2013. 00346.

Bai, X, Yang, L, Tian, M, Chen, j, Shi, J et al. (2011). Nitric oxide enhance dessication tolerance of recalcitrant Antiaris toxicaria seeds via protein Snitrosylation and carbonylation. Plos One, 6(6): e20714. Doi:10.1371/journal. pone.0020714.

Beligni, M V and Lamattina, L (2000). Nitric oxide stimulates seed germination and de-etiolation, and inhibits hypocotyl elongation, three light-inducible responses in plants. Planta 210, 215-221.

Bergh, B (1988). The effect of pretreatments on avocado seed germination. California Avocado Society. Yearbook 72, 215-221.

Bethke, P C, Gubler, F, Jacobsen, J V and Jones R L (2004). Dormancy of Arabidopsis seeds and barley grains can be broken by nitric oxide. Planta 219, 847-855.

Bethke, P C, Libourel, I, Reinhol, V and Jones, R L (2006a). Sodium nitroprusside, cyanide, nitrate and nitrite break Arabidopsis seed dormancy in a nitric oxide dependent manner. Planta 223(4), 805-12.

Bethke, P C, Libourel, I G, and Jones, R L (2006b). Nitric oxide reduces seed dormancy in Arabidopsis. Journal of Experimental Botany 57, 517-526. doi: 10.1093/jxb/erj060.

Bewley, J D (1997). Seed germination and dormancy. Plant Cell 9, 1055-1066. doi:10.1105/tpc.9.7.1055.

Chin, H F (1995). Storage of recalcitrant seeds. In: Basra A.S. (Ed) Seed Quality, Basic Mechanisms and Agriculture Implications. The Haworth Press, Inc. NY, USA, pp.209-222. 
Nitric oxide improves germination of rubber seeds

Chohan, A, Parmar, U and Raina, S K (2012). Effect of sodium nitroprusside on morphological characters under chilling stress in chickpea (Cicer arietinum L.). Journal Environmental Biology 33, 695-698.

Correa-Aragunde, N, Graziano, $\mathrm{M}$ and Lamattina, L (2004). Nitric oxide plays a central role in determining lateral root development in tomato. Planta 218, 900-905. doi: 10.1007/s00425-0031172-7.

da Silva E A, Toorop, P E, van Aelst, A C and Hilhorst, H W (2004). Abscisic acid controls embryo growth potential and endosperm cap weakening during coffee (Coffea arabica cv Rubi) seed germination. Planta 220, 251-261.

Dorna, H, Li, W and Szopińska, D (2014). The effect of priming on germination and vigour of pansy (viola $\times$ wittrockiana Gams.) seeds. Acta Scientiarum Polonorum Hortorum Cultus, 13(6), 15-29.

Duan, P, Ding, F, Wang, F and Wang, B S (2007). Priming of seeds with nitric oxide donor sodium nitroprusside (SNP) alleviates the inhibition on wheat seed germination by salt stress. Journal of Plant Physiology and Molecular Biology 33, 244-250.

Filho, J M (2005). Fisiologia de sementes de plantas cultivadas. Piracicaba: Fealq.

Ghassemi-Golezani, K, Alilool, A A, Valizadeh, M and Moghaddam (2008). Effects of hydro and osmo-priming on seed germination and field mergence of lentil (Lens culinaris Medik.). Notulae Botanicae Horti Agrobotanici 36(1), 2933.

Girardi, E A, Filho, F A M M and Kluge, R A (2007). Effect of seed coat removal and controlled-release fertilizer application on plant emergence and vegetative growth of two citrus rootstocks. Fruits 62, 13-19.

Gubler, F, Millar A A and Jacobsen, J V (2005). Dormancy release, ABA and pre-harvest sprouting. Current Opin. in Plant Biology 8, 1-5.

Habib, N, Ashraf, M and Ahmad, M S A (2010). Enhancement in seed germinability of rice (Oryza sativa 1 .) by pre-sowing seed treatment with nitric oxide (no) under salt stress. Pakistan Journal of Botany 42(6), 4071-4078.

Hua, Z, Wen-Biao, S and Lang-Lai, X U (2003). Effect of nitric oxide on the germination of wheat seeds and its reactive oxygen species metabolism under osmotic stress. Acta Botanica Sinica 45 (8), 901-905.

Kimura, E and Islam, M A (2012). Seed scarification method and their use in forage legumes. Research Journal of Seed Science 5(2), 38-50

Kong, J Y, Dong, L, Xu, S, Liu, and X Bai (2014). Effects of foliar application of salicylic acid and nitric oxide in alleviating iron deficiency induced chlorosis of Arachis hypogaea L. Botanical Stud. 55(9), 1-9.

Liu, Y, Shi, L, Ye, N, Liu, W and Zhang, J (2009). Nitric oxide-induced rapid decrease of abscisic acid concentration is required in breaking seed dormancy in Arabidopsis. New Phytologist 183, 1030-1042.

McDonald, M B (2004). Orthodox seed deterioration and its repair. In: Benech Arnold RL, Sánchez RA (Eds.) Handbook of Seed Physiology, Application to Agriculture, Haworth Press, Inc, NY, USA, pp. 273-298.

Morris, E C, Tieu, A and Dixon, K (2000). Seed coat dormancy in two species of Grevillea (Proteaceae). Annals of Botany 86, 771-775. 
N M C Nayanakantha et al.

Mur, L A J, Mandon, J, Persijn, S, Cristescu, S M, Moshkov, I E, Novikova, G V, Hall, M A, Harren, F J M, Hebelstrup, K H and Gupta, K J (2012). Nitric oxide in plants: an assessment of the current state of knowledge. AoB PLANTS 5: pls052; doi:10.1093/aobpla/pls052.

Muralidhara, B M, Reddy, Y T N, Srilatha, $\mathrm{V}$ and Akshitha, H J (2016). Effect of seed coat removal treatments on seed germination and seedling attributes in mango varieties. International Journal of Fruit Science 16(1), 1-9. DOI: 10.1080/ 15538362. 2015.1021885. pp.

Nayanakantha, N M C, Pathirana, P D, Senevirathna, A M W K and Seneviratne, $P$ (2014). Exogenous nitric oxide-donor sodium nitroprusside ameliorates root architecture and growth of young budding polybagged plants of rubber (Hevea brasiliensis). Journal of the Rubber Research Institute of Sri Lanka 94, 9-24.

Nugawela, A (2010). Rubber research in Sri Lanka - The past 100 years and the future. Bulletin of the Rubber Research Institute of Sri Lanka 51, 28-35.

Pagnussat, G C, Simontacchi, M, Puntarulo, S and Lamattina, L (2002). Nitric oxide is required for root organogenesis. Plant Physiology 129, 954-956.

Pandey, A and Tamta, S (2013). Effect of pre-sowing treatments on seed germination in Quercus serrata Thunb. and Quercus semecarpifolia Sm. Int. J. of Biodiversity and Cons., 5(12), 791795.

Paul, D, Paul, N K and Basu, P K (2008). Seed germination response of Rauvolfia serpentina benth to certain physical and chemical treatments. Journal of Biological Sciences 16, 129-131.

Radhamani, J, Malik, S K and Chandel, K P $S$ (1991). Seed coat characteristics in relation to the physiology of seed germination in Citrus and its allied genus. Seed Science \& Technology, 19, 611-621.

Rawat, D C S, Thapliyal, P and Nautiyal, A R (1998). Pericarp delays germination in Quercus glauca Thunb seeds. Journal of Tropical Forest Science 10, 472-477.

Saeed, M and Thanos, C A (2006). The effect of seed coat removal on seed germination of Pinus gerardiana Wallich ex D. Don. Chilgoza pine. Journal of Applied and Emerging Science 1 (3), 174-177.

Sarath, G, Bethke, P C, Jones, R, Baird, L M, Hou, G and Mitchell, R B (2006). Nitric oxide accelerates seed germination in warm-season grasses. Planta 223, 1154-1164.doi: 10.1007/ s00425-005-0162-3.

Sempionato, O R, Girotto L F and Stuchi, E S (1997). Produção de mudas sadias, In: Donadio L C, Moreira, C S (Eds.), Clorose variegada dos citros, Fundecitrus, Bebedouro, Brasil.

Seneviratne, $\mathrm{P}$ and Wijesekara, G A S (2011). The growth pattern of rubber tree to improve the performance of clearings. Bulletin of the Rubber Research Institute of Sri Lanka 52, 26-30.

Zhang, M, An, L, Feng, H, Chen, T, Chen, K, Liu, Y, Tang, H, Chang, J and Wang, $X$ (2003). The cascade mechanisms of nitric oxide as a second messenger of ultraviolet B in inhibiting mesocotyl elongations. Photochem. and Photobiol. 77, 219-225.

Address for correspondence: Dr N M C Nayanakantha, Head, Plant Science Dept., Rubber Research Institute of Sri Lanka, Dartonfield, Agalawatta, Sri Lanka. e-mail: nayanakanthachamil7@gmail.com 